\title{
EFL Students' Perception of the Use of Grammarly Application in Writing Class
}

\author{
Ghaida Nurul Rahma Hakiki \\ Universitas Tidar, Magelang, Indonesia \\ Email: ghaida.hakiki@gmail.com
}

\begin{abstract}
As an EFL students, we cannot separate from writing assignments and articles in English. For some students, it is not easy to express thoughts with good grammar directly. They often require several repetitions of works to avoid making mistakes. Even so, they still make a mistake in grammar. Grammatical errors in the writing class often make it difficult for lecturers to understand student writing content so that students get unsatisfactory feedback. One solution to this problem is implementing the Grammarly application in writing assignments and articles. This study aims to determine students' views on using the Grammarly application in writing assignments and articles. This study uses a qualitative approach with descriptive analysis methods. The research subjects were students of the fifth semester of English Language Education, FKIP Tidar University. The research data used an automatic grammar checker in the learning process of writing namely Grammarly.
\end{abstract}

Keywords: Grammarly, learning process, writing.

\section{INTRODUCTION}

In writing, EFL students are expected to produce text or messages to convey knowledge to others. Though, it should be noted that writing is an individual product and a social act. In line with this statement, Lyons and Kroll (Weigle, 2002) define writing as actions that occur in context, which achieve certain goals, and which are shaped appropriately for the intended audience. Thus, writing is not only for producing text but also for interacting with other people in a social act.

Writing, according to Spratt, Pulverness, and Williams (2005), is defined as one of four language skills. This means that writing is one of the most prominent skills that English learners must master. Like Spratt, Pulverness, and Williams, Burroway (2002) states that writing is a solitary struggle. This means that every English learner must master this ability individually because writing is a productive skill. According Daniels \& Leslie (2013) in an EFL writing class, adduce, it is a natural extension to provide students with opportunities for authentic foreign language interaction through technology.

Compared to other skills, writing has always been considered a difficult skill to learn. This is an activity that raises its own concerns for students. This is because many students still have difficulty applying their grammar knowledge. When students collect their writing results, they get feedback 
in lecturers' disappointment because they have difficulty understanding student writing content. According to Wichadee (2013) Feedback is a traditional instructional tool for writing the course to improve the students' writing skills. It can be used to highlight the errors in EFL writing tasks, i.e., grammatical errors, spelling errors, diction errors, and so on.

According to Collins (2018), writing is a group of letters or symbols written or marked on a surface to communicate ideas by making each symbol stand for an idea, concept, or thing, by using each symbol to represent a set of sounds grouped into syllables. During Charrouf (2015) says that writing is not a language skill that can be gained instantly without process, especially for EFL learners. Some aspects or elements need to be understood and mastered by the learner to have good writing skills, such as sentence structure, word choice, writing organization, coherence, and any other elements.

Suriamiharja (1996) argues that writing is a communication activity to express thoughts, feelings, and wills to others in writing. Richards and Renandya (2002) emphasize that writing skills are very complex; therefore, it is necessary to acquire various skills to write effectively. In particular, they should pay attention to "higher-level skills of planning and organizing as well as lower skills of spelling, punctuation, word choice, and so on." Richards and Renandya also suspect that if their language skills are weak, they will face great writing difficulties.

When we writing, we also use grammar. Chomsky (1965) said that Grammar is a system of rules that can produce many structural rules. Based on his opinion, the system of rules is grouped into three main grammar components: syntax, phonology, and semantics (Hariyanto, 2007). Regarding language sounds according to their function, the syntax is knowledge of word and sentence structure, phonology is knowledge, while semantics is the science of word meaning (Suharso and Retnoningsih, KBBI).

Alex Shevchenko and Max Lytvyn in 2008 developed Grammarly that can check grammar and written context in English. Grammarly has various advantages, including Grammar Checker, Proofreading, and Plagiarism. This application can provide input on correct spelling so that the context of the sentence becomes correct, corrects errors in word usage, and with this recommendation from Grammarly, the user's vocabulary will increase. This is consistent with what was conveyed by McAlexander (2000) "grammar checkers are fundamentally patterned matches; hence they are most reliably helpful on formulaic problems." Grammarly is an application created to assist writers / EFL students in writing English articles. Using this application, lecturers can quickly improve vocabulary and simple grammar without learning about English grammar or dictionary.

\section{METHODOLOGY}

This is a qualitative descriptive study. In Lexy J. Moleong (2014: 4), Bogdan Taylor (1975: 5) defines qualitative research as a research procedure that produces descriptive data in written or spoken words from people and observable behavior. This approach is directed at the setting and the individual 
holistically. With the descriptive method, researchers analyzed the data collected in words, pictures, and not numbers. The data comes from interview manuscripts, field notes, photos, videotapes, personal documents, notes or memos, and other official documents.

The subject of this research is the Grammarly application program obtained from the internet, which can be downloaded for free. Then by registering a Grammarly account, we can use this application to improve the writing of our articles or writing. In contrast, the informants in this study were students of the 5th semester of the English Education Study program at Tidar University. Determination of the subject is based on purposive sampling technique, meaning that the determination of the sample considers certain criteria that have been made for objects that are in accordance with the research objectives (Sugiyono, 2012, 117) This research's object is data from all forms of interaction between researchers and informants through questionnaires distributed by researchers. Furthermore, it is analyzed qualitatively to determine the lecturers' perceptions of using Grammarly. The steps taken in analyzing the data are as follows the following: (a) Collecting the results of interviews and questionnaires, (b) Reading carefully, reducing data, and selecting data according to the focus of the study, (c) Interpreting and analyzing data, (d) Describing the results of the study and compiling conclusions.

\section{FINDING AND DISCUSSION}

From the results of the study, based on data collected from questionnaires, the authors present the findings and discussion of research to answer research questions about the Perception of Fifth Semester EFL Students on the Use Grammarly Application in Writing Class. The research was conducted at Tidar University, especially for fifth semester English language students who have an Essay Writing course.

This questionnaire was distributed to all fifthyear English Education students through the messaging application on Thursday, December 3, 2020. Furthermore, the researchers obtained the results of the questionnaire data on Thursday, December 10, 2020. From all questionnaire feedback, the survey data revealed that 44 students filled in a questionnaire for Grammarly research as a tool to check for grammar mistakes in their essay writing.

There are 15 questions distributed by the researcher. Through a questionnaire, the researcher wants to find out about students' perceptions about the use of Grammarly in two aspects, namely the use and quality of Grammarly as a grammar checking tool in writing English students in essay writing. The questionnaire used close-ended questions to collect data. There are five alternative answers available in each question: strongly disagree, disagree, agree, and strongly agree. 


\begin{tabular}{|c|c|c|c|c|c|}
\hline \multicolumn{6}{|c|}{ EFL students "eabout their awareness of Grammarly and other grammar checking tools to support their essay writing. } \\
\hline Response & $\begin{array}{l}\text { Strongly } \\
\text { Disagree }\end{array}$ & Disagree & Neutral & Agree & $\begin{array}{l}\text { Strongly } \\
\text { Agree }\end{array}$ \\
\hline $\begin{array}{l}\text { Before I meet Grammarly, I use another grammar checker tool, } \\
\text { but it does not really helpful for writing my English essay. }\end{array}$ & 0 & $\begin{array}{l}6 \\
14.0 \%\end{array}$ & $\begin{array}{l}11 \\
25.6 \%\end{array}$ & $\begin{array}{l}24 \\
55.8 \%\end{array}$ & $\begin{array}{l}2 \\
4.7 \%\end{array}$ \\
\hline $\begin{array}{l}\text { The grammar checker tool that I usually use for checking my } \\
\text { English essay writing grammar is grammarly. }\end{array}$ & 0 & 0 & $\begin{array}{l}6 \\
14.0 \%\end{array}$ & 22 & $\begin{array}{l}15 \\
34.9 \%\end{array}$ \\
\hline
\end{tabular}

Table 4.1

From the table above, it can be seen that almost all students agree and strongly agree that Grammarly is the first grammar check application they know and is a grammar check application that can help them to write their essay writing.

First, from the results of questionnaires number 3 to 7 , students were asked about their perceptions of using Grammarly as a means of checking English grammar to support them in writing their essays. Grammarly's suggestions include clear, easy to understand, easy to use, have grammatical accuracy, and can correct mistakes quickly.

Second, from questionnaires 8 to 10 , they get statements about their perceptions of using Grammarly in improving their English writing skills, especially in writing English essays. Namely, Grammarly is developing English writing skills, increasing student confidence in writing academic texts, and understanding English grammar rules. Table 4.2

EFL Students' perceptions of the usefulness of Grammarly in writing their English essays

\begin{tabular}{|c|c|c|c|c|c|}
\hline Response & $\begin{array}{l}\text { Strongly } \\
\text { Disagree }\end{array}$ & Disagree & Neutral & Agree & $\begin{array}{l}\text { Strongly } \\
\text { Agree }\end{array}$ \\
\hline $\begin{array}{l}\text { I think Grammarly is really easy to use for } \\
\text { writing my essay }\end{array}$ & $\begin{array}{r}0 \\
0.0 \%\end{array}$ & $\begin{array}{r}1 \\
2.3 \%\end{array}$ & $\begin{array}{r}4 \\
9.3 \%\end{array}$ & $\begin{array}{r}23 \\
53.5 \%\end{array}$ & $\begin{array}{r}15 \\
34.9 \%\end{array}$ \\
\hline $\begin{array}{l}\text { Grammarly makes helpful suggestions for improving } \\
\text { my English essay writing. }\end{array}$ & $\begin{array}{r}0 \\
0.0 \%\end{array}$ & $\begin{array}{r}1 \\
2.3 \%\end{array}$ & $\begin{array}{r}5 \\
11.6 \%\end{array}$ & $\begin{array}{r}30 \\
69.8 \%\end{array}$ & $\begin{array}{r}7 \\
16.3 \%\end{array}$ \\
\hline $\begin{array}{l}\text { Grammarly gives good explanations for my errors in } \\
\text { writing my essay. }\end{array}$ & $\begin{array}{r}1 \\
2.3 \%\end{array}$ & $\begin{array}{r}1 \\
2.3 \%\end{array}$ & $\begin{array}{r}9 \\
20.9 \%\end{array}$ & $\begin{array}{r}26 \\
60.5 \%\end{array}$ & $\begin{array}{r}6 \\
14.0 \%\end{array}$ \\
\hline $\begin{array}{l}\text { I like to use Grammarly because it has } 100 \% \text { of } \\
\text { grammar accuracy for checking my grammar errors } \\
\text { compared to any other of grammar checkers tools. }\end{array}$ & $\begin{array}{r}1 \\
2.3 \%\end{array}$ & $\begin{array}{r}3 \\
7.0 \%\end{array}$ & $\begin{array}{r}21 \\
48.8 \%\end{array}$ & $\begin{array}{r}17 \\
39.5 \%\end{array}$ & $\begin{array}{r}1 \\
2.3 \%\end{array}$ \\
\hline $\begin{array}{l}\text { I think Grammarly has faster correction than any } \\
\text { other of grammar checkers tools that I know. }\end{array}$ & $\begin{array}{r}0 \\
0.0 \%\end{array}$ & $\begin{array}{r}0 \\
0.0 \%\end{array}$ & $\begin{array}{r}17 \\
39.5 \%\end{array}$ & $\begin{array}{r}17 \\
39.5 \%\end{array}$ & $\begin{array}{r}9 \\
20.9 \%\end{array}$ \\
\hline \multicolumn{6}{|c|}{ EFL Students' perceptions of the usefulness of Grammarly in improving their writing skills } \\
\hline $\begin{array}{l}\text { Grammarly is very useful in developing my writing } \\
\text { skills, especially for my English essay writing. }\end{array}$ & $\begin{array}{l}0 \\
0.0 \%\end{array}$ & $\begin{array}{l}0 \\
0.0 \%\end{array}$ & $\begin{array}{l}10 \\
23.3 \%\end{array}$ & $\begin{array}{l}28 \\
65.1 \%\end{array}$ & $\begin{array}{l}5 \\
11.6 \%\end{array}$ \\
\hline
\end{tabular}




\begin{tabular}{|c|c|c|c|c|c|}
\hline $\begin{array}{l}\text { With Grammarly, I have more confidence in writing } \\
\text { my academic texts, especially in writing my English } \\
\text { essay writing. }\end{array}$ & $\begin{array}{l}0 \\
0.0 \%\end{array}$ & $\begin{array}{l}0 \\
0.0 \%\end{array}$ & $\begin{array}{l}5 \\
11.6 \%\end{array}$ & $\begin{array}{l}32 \\
74.4 \%\end{array}$ & $\begin{array}{l}6 \\
14.0 \%\end{array}$ \\
\hline $\begin{array}{l}\text { I think Grammarly has helped me to more } \\
\text { understand about English grammar rules. }\end{array}$ & $\begin{array}{l}0 \\
0.0 \%\end{array}$ & $\begin{array}{l}2 \\
4.7 \%\end{array}$ & $\begin{array}{l}10 \\
23.3 \%\end{array}$ & $\begin{array}{l}29 \\
67.4 \%\end{array}$ & $\begin{array}{l}2 \\
4.7 \%\end{array}$ \\
\hline
\end{tabular}

Table 4.2

Based on the data in table 4.2, most students agree to strongly agree that Grammarly is useful to support them in writing their English essays. From the table above, it can be seen that almost all students stated that Grammarly was easy to use to write their essays. However, some students could not define it by choosing neutral, and 1 child stated that he had difficulty using Grammarly. Grammarly's suggestions, almost all students agree or strongly agree that Grammarly provides useful suggestions to improve their essay writing when they make mistakes, only 5 children still cannot define, and 1 child disagrees. Then, for the explanation given by Grammarly, the answers were very diverse, some 9 students who could not define by choosing neutral, that when students make mistakes in writing their essays, and then they check it in Grammarly, Grammarly can provide a good explanation about it, meanwhile 26 students agreed, and 6 students strongly agreed on this. However, 2 children strongly disagreed and disagreed with the statement.

Then 1 student strongly disagrees that Grammarly has $100 \%$ grammar accuracy. 3 children disagreed, while those in a neutral position had the most votes, namely 21 students, where it was possible that they did not really understand whether Grammarly's grammar was accurate or not. Furthermore, 18 children chose to agree to agree about Grammarly's grammar's accuracy strongly to follow Grammarly's writing suggestions.

Most students either agreed or strongly agreed that Grammarly had faster corrections for quicker correction than any existing grammar proofing tool, while the rest chose neutral. Grammarly has a feature to check documents by uploading them to Grammarly via Grammarly.com; by uploading them, Grammarly can check all the text in the uploaded documents. Although other language proofing tools also exist that can upload files, Grammarly is still considered the fastest in the process.

In table 4.2, it can be seen that only 10 students are neutral about the usefulness of Grammarly in improving their writing skills, while the rest agree or strongly agree about it.

From the questionnaire using Grammarly, they have more confidence in writing their English essay, or any academic text, almost all students agree or strongly agree. Meanwhile, 5 students chose neutral.

The next questionnaire asked about the use of Grammarly in helping them to understand the rules of English grammar better, especially when it comes to writing essays or any academic text, 2 people disagreed, and 10 students chose neutral. The rest chose to agree to agree strongly. 
A questionnaire from 11 to 15 aims to determine student perceptions about the quality of the free version of the grammar check tool and its features.
Below are the results EFL students' perceptions about the quality of Grammarly software or applications for writing essays

\begin{tabular}{|c|c|c|c|c|c|}
\hline \multicolumn{6}{|c|}{ EFL students' perceptions about the quality of Grammarly software or applications for essay writing } \\
\hline Response & $\begin{array}{l}\text { Strongly } \\
\text { Disagree }\end{array}$ & Disagree & Neutral & Agree & $\begin{array}{l}\text { Strongly } \\
\text { Agree }\end{array}$ \\
\hline $\begin{array}{l}\text { I think the free version of Grammarly is really helpful } \\
\text { for me as a university student in checking my essay } \\
\text { writing's grammar. }\end{array}$ & $\begin{array}{r}0 \\
0.0 \%\end{array}$ & $\begin{array}{r}5 \\
11.6 \%\end{array}$ & $\begin{array}{r}15 \\
34.9 \%\end{array}$ & $\begin{array}{r}19 \\
44.2 \%\end{array}$ & $\begin{array}{r}4 \\
9.3 \%\end{array}$ \\
\hline $\begin{array}{l}\text { I think the free version of Grammarly has a good quality } \\
\text { to support to check the grammar errors of my English } \\
\text { essay writing }\end{array}$ & $\begin{array}{r}0 \\
0.0 \%\end{array}$ & $\begin{array}{r}8 \\
18.6 \%\end{array}$ & $\begin{array}{r}15 \\
34.9 \%\end{array}$ & $\begin{array}{r}19 \\
44.2 \%\end{array}$ & $\begin{array}{r}1 \\
2.3 \%\end{array}$ \\
\hline $\begin{array}{l}\text { I think the free version of Grammarly is really useful } \\
\text { to help me to check the grammar in Google Translate } \\
\text { easily. }\end{array}$ & $\begin{array}{r}0 \\
0.0 \%\end{array}$ & $\begin{array}{r}6 \\
14 \%\end{array}$ & $\begin{array}{r}16 \\
37.2 \%\end{array}$ & $\begin{array}{r}20 \\
46.5 \%\end{array}$ & $\begin{array}{r}1 \\
2.3 \%\end{array}$ \\
\hline $\begin{array}{l}\text { I like to use Grammarly because it has many good } \\
\text { features compared to any other of grammar checkers } \\
\text { tools. }\end{array}$ & $\begin{array}{r}0 \\
0.0 \%\end{array}$ & $\begin{array}{r}1 \\
2.3 \%\end{array}$ & $\begin{array}{r}10 \\
23.3 \%\end{array}$ & $\begin{array}{r}28 \\
65.1 \%\end{array}$ & $\begin{array}{r}4 \\
9.3 \%\end{array}$ \\
\hline $\begin{array}{l}\text { It is really recommended to use Grammarly for checking } \\
\text { the grammar errors of an English essay writing. }\end{array}$ & $\begin{array}{r}0 \\
0.0 \%\end{array}$ & $\begin{array}{r}0 \\
0.0 \%\end{array}$ & $\begin{array}{r}7 \\
16.3 \%\end{array}$ & $\begin{array}{r}31 \\
72.1 \%\end{array}$ & $\begin{array}{r}5 \\
11.6 \%\end{array}$ \\
\hline
\end{tabular}

Table 4.3

From table 4.3, the Grammarly questionnaire has a good quality to support English students in writing essays; as many as 5 children disagree if the free version of Grammarly is very helpful for checking their grammar errors in their essays, 23 students agree to agree strongly, and the rest chose neutral.

Although there are 2 versions of Grammarly, namely free and premium, the free version is enough to help students improve their grammar. However, 8 students still disagreed with it, while 15 others chose neutral, and the rest chose to agree to agree strongly.

Grammarly can also be used using add-ons or extensions in several web browsers by downloading it first, which can then be used directly on Google translate, email, Facebook, and others. We cannot deny that as EFL students, we still often use google translate. However, the results of google translate sometimes become strange and difficult to understand. With this extension, students can immediately use Grammarly on google translate not to bother going back and forth between the google translate web and the Grammarly web. The essay writing process becomes easier.

Many features are in Grammarly; from the features provided in free mode, 1 student does not agree that Grammarly has many more good features than other grammar checking tools. The other 10 
students thought they were neutral, and the rest chose to agree until they completely agreed.

The last is students who use Grammarly in writing essays 7 of them choose neutral to recommend Grammarly in using the essay writing process to check for grammatical errors in their essays. Meanwhile, most of the students agreed to strongly agree. After they have finished writing the essay, they can upload their essay file to the grammarly.com web wherein a short time, and they can see which words or sentences they need to improve.

The author takes a research question about the Perception of Fifth Semester EFL Students on the Use Grammarly Application in Writing Class from the research that has been done. It consists of EFL students 'perceptions about the use of Grammarly in writing essays and in improving writing skills, and EFL students' perceptions of the quality of the Grammarly software itself for writing.

According to Jalaluddin Rahmat perception is the experience of objects, events some relations obtained by inferring information and interpret the message. There are 3 main perceptions of the data obtained: negative, neutral, and positive perceptions. Based on Robbins (2002), negative perceptions are about a person's dissatisfaction with the source (object) of their perceptions. Positive perception is about a person's assessment of an object or information with a positive outlook or expectation from the object being perceived. Meanwhile, according to the author, students who answered "neutral" could not define what he felt. Students tend to be confused and have not had a meaningful experience, so their perceptions are neutral.
Robbins and Judge (2013) explain that three factors influence perception: perceiver (object), target, and situation. In this case, the main concern is the perceiver (object), where the object is the fifth semester of Tidar University EFL students who use Grammarly to help write their essays.

\section{CONCLUSION}

This study aims to know the perception of fifthsemester EFL students on the use of Grammarly application in writing class at Tidar University.

From the results of this study, EFL students from the 5th semester of the English Department generally gave a positive perception: Grammarly is useful in writing English essays. That's because it's easy to use, helpful advice, easy to understand explanations, good grammar accuracy, and faster corrections. Besides, the use of Grammarly is useful in improving writing skills and students' self-confidence in writing, especially in writing essays. Through Grammarly, they can also learn more English grammar rules. After using Grammarly in their essay writing process, students also believe that the Grammarly application is good for writing English essays. Even though they only use Grammarly with the free version, almost all students agree that it is really recommended to use Grammarly to support English students in writing English essays. It can be concluded that most students consider that Grammarly is indeed useful to support EFL students in writing essays. 


\section{REFERENCES}

Burroway, Janet. 2002. Writing Fiction a Guide to Narrative Craft. New York: Pearson Education.

Charrouf, A. (2015). Improving EFL Students' Writing Skill through a Directed Blog Case of Students at Mohamed Khider University of Biskra A dissertation submitted in partial fulfilment for the requirements for The Master of Arts Degree in Language Sciences.

Chomsky, N., 1965. Aspects of the Theory of Syntax. MIT Press, Cambridge, MA.

Collins, W. (2018). Writing defined. Retrieved from: http://www.collinsdictionary.com/dictionary/englis $\mathrm{h} /$ writing

Daniels, P., \& Leslie, D. (2013). Grammar software ready for EFL writers? OnCue Journal, 9(4), 391-401.

Hariyanto. (2007). A Study on the Correlation between Grammar Mastery, Indirect Learning Strategies and Reading Ability of the Second Grade Students of SMK Batik 1 Surakarta. Skripsi. Surakarta:UNS

Novianti, Erynda (2020) EFL Students' Perceptions on the Use of Grammarly in Writing Thesis. Skripsi, Tarbiyah dan Keguruan.

McAlexander, P. J. (2000). Checking the Grammar Checker: Intergrating Grammar Instruction with Writing. Journal of Basic Writing Vol. 19 No.2

Moleong,J.L (2010) Metode Penelitian Kualitatif. Bandung: PT Remaja Rosdakarya
Pujiawati, N. I. A. (2018). Mengintegrasikan Automatic Grammar Checker, 6, 1-11. http://journal.unsika. ac.id/index.php /judika

Rakhmat, Jalaludin. (2007). Psikologi Komunikasi. Bandung. Remaja Rosdakarya.

Richard, J., \& Renandya, W. (2002). Methodology in language teaching: An Anthology of Current Practice. New York: Cambridge University Press.

Robbin, S. P. (2002). Perilaku Organisasi. Jakarta : Prenhallindo.

Robbins, S. P., \& Judge, T. A. (2013). Organizational Behavior 15th Edition. New Jersey: Pearson Education.

Spratt, Mary., Pulverness, A., Williams, Melanie. 2005. The Teaching Knowledge Test Course. Cambridge: Cambridge University Press.

Sugiyono. (2012). Metode Penelitian Kuantitatif Kualitatif dan R\&D. Bandung: Alfabeta

Suramiharja, A., et al. (1996). Petunjuk Praktis Menulis. Jakarta: Departemen Pendidikan dan Kebudayaan

Weigle, S.C. 2002. Assessing Writing. Cambridge: Cambridge University Press.

Wichadee, S. (2013). Peer feedback on Facebook: The use of social networking websites to develop writing ability of undergraduate students. Turkish Online Journal of Distance Education, 14(4), 260-270. https://doi.org/10.17718/TOJDE.25470. 